$1 / v e E / k T$, where $E / k T$ is a signal-to-noise ratio and $v$ is the vibrational frequency of the bond, about $10^{13} \mathrm{e} / \mathrm{s}$ For a signal-to-noise ratio of four, this brief interaction would last only $10^{-11} \mathrm{sec}$, the time required for a sodium ion to diffuse only a few angstroms in the absence of an electrochemical gradient.

This work was supported by the U.S. Atomic Energy Commission.

Horton A. Johnson

KNUD D. KNUDSEN

Medical Research Center,

Brookhaven National Laboratory, Upton, New York.

${ }^{1}$ Borsook, H., and Winegarden, H. M., Proc. U.S. Nat. Acad. Sci., 17, 3 (1931).

${ }^{2}$ Newburgh, J. D., J. Clin. Invest., 22, 439 (1943).

${ }^{3}$ Rapoport, S., Brodsky, W. A., West, C. D., and Mackler, B., Science, 108, $630(1948)$.

- Smith, H. W., The Kidney: Structure and Function in Health and Disease (Oxford Univ. Press, New York, 1951).

${ }^{5}$ Wiener, N., Cybernetics (Wiley, New York, 1948).

' Johnson, H. A., Science, 141, 910 (1963).

"Johnson, H. A., Perspectives in Biol. and Med., 8, No. 3 (1965, in the press).

${ }^{8}$ Brillouin, L., Science and Information Theory (Academe Press, New York,

'Szilard, L., Z. Physik., 58, 840 (1929).

${ }^{10}$ Van Slyke. D. D., Rhoads, C. P., Hiller, A., and Alving, A. S., Amer. $J$. Physiol., 109, 336 (1934).

${ }^{11}$ Polanyi, M., and Wigner, E., Z. Physik. Chem., 139, 439 (1928).

\section{Dephosphorylation of Polynucleotides and some of their Components by Ultra-violet Irradiation}

RECENTLY, the dephosphorylation of sugar phosphates of carbohydrate metabolism by ultra-violet light has been reported by us ${ }^{1}$. The work recorded here deals with the phosphatatic aetivity of ultra-violet radiation on polynucleic acids and ribonucleotides.

The aqueous solutions of ribonucleic acid and deoxynucleic acid $\left(50 \mathrm{ml}\right.$. of $10^{-3}$ molar (molecular weights of the substances are calculated from the phosphorus content of the compounds); $p \mathrm{H}=4-5$; temp. $=20^{\circ} \mathrm{C}$ ) were irradiated for I $\mathrm{h} ; 75 \gamma$ split inorganic phosphate was found in both cases. It seems that the polynucleotides are, first of all, depolymerized to mononucleotides which subsequently undergo hydrolysis ${ }^{2}$. A similar phenomenon is also observed in the radiation of bacteria ${ }^{3}$. This explains the slow dephosphorylation of these substrates as compared to mononucleotides (Fig. 1).

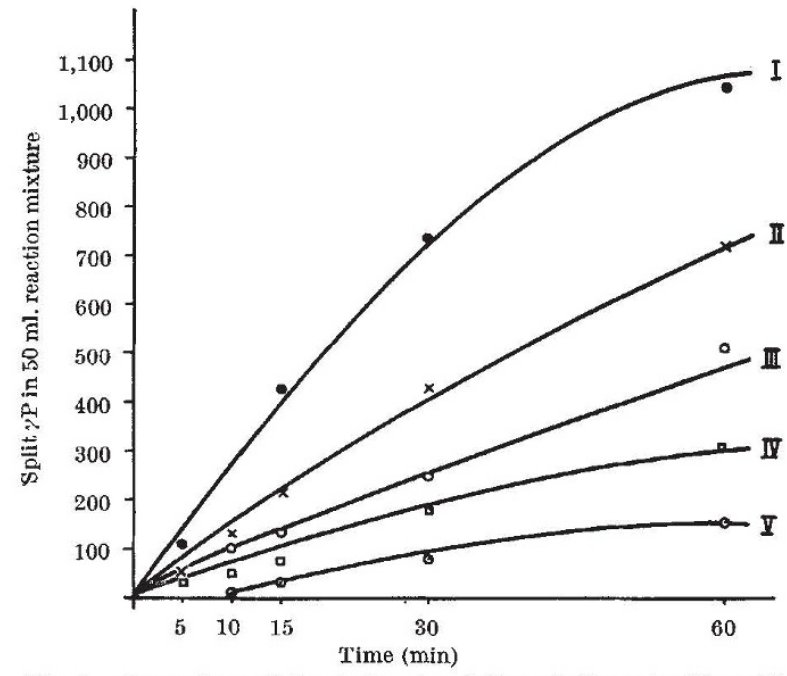

Fig. 1. Comparison of the dephosphorylation of ribonucleotides with ultra-violet radiation at $p \mathrm{H}=3.5 ;$ temperature $=20^{\circ}$. Uridine hosphate (III); adenosine $2^{\prime}, 3^{\prime}$-phosphate (IV); adenosine $5^{\prime}$-phosphate $(V)$
It is evident that the pyrimidine nucleotides (uridine $2^{\prime}, 3^{\prime}$ - and cytidine $2^{\prime}, 3^{\prime}$-phosphates) are hydrolysed more rapidly than purine nucleotides (guanosine $2^{\prime}, 3^{\prime}$ - and adenosine $2^{\prime}, 3^{\prime}$-phosphates). It is well known that pyrimidine and purine ring systems absorb ultra-violet light; however, the former is more sensitive to $\mathrm{it}^{4,5}$. Further, the destruction of pyrimidine nucleotides is also noted in the irradiated bacterial cells ${ }^{3}$.

The difference in degree of hydrolysis between $2^{\prime}, 3^{\prime}$ uridylic acid and $2^{\prime}, 3^{\prime}$-cytidylic acid as well as between $2^{\prime}, 3^{\prime}$-guanylic acid and $2^{\prime}, 3^{\prime}$-adenylic acid can be explained on the assumption that the phosphate group forms a hydrogen bond with the $-\mathrm{NH}_{2}$ group at $\mathrm{C}_{6}$ in $2^{\prime}, 3^{\prime}$-ester of cytidylic and adenylic acids, which may ultimately result in slow dephosphorylation of these substrates with ultra-violet light.

We adopted the methods for the estimation of inorganic phosphate and other experimental details as described earlier ${ }^{6} ; 50 \mathrm{ml} .10^{-3}$ molar aqueous solution of the sub. strate was irradiated each time. Initial hydrolysis of the esters was subtracted from the final readings.

This work was supported by the German Research Association (Deutsche Forschungsgemeinschaft).

\section{H. TrapmanN \\ M. Devani}

Institut für Pharmazie und

Lebensmittelchemie der Universität,

München, und Akademie des Sanitäts- und

Gesundheitswesens der Bundeswehr, München.

1 Trapmann, H., and Devani, M., Naturwiss. (in the press).

2 Seraydarian, M., Canzanelli, A., and Rapport, D., Amer. J. Physiol., 172, $42(1953)$.

${ }^{3}$ Loofbourow, J. R., Oppenheimer-Errera, S., Loofbourow, D. G., and Yeats, C. A., Biochem. J., 41, $122(1947)$

4 Rapport, D., and Canzanelli, A., Science, 112, 469 (1950).

${ }^{5}$ Sinsheimer, R. L., and Hastings, R., Science, 110, 525 (1949).

'Bamann, E., Gubitz, K., and Trapmann, H., Arch. Pharm., 294, 240 (1961).

\section{Relationship of Dietary Intake of Sulphur Amino-acids to Urinary Excretion of Inorganic Sulphate in Man}

As early as 1905 , Wendt ${ }^{1}$ pointed out the importance of determining urinary sulphur in studies of protein metabolism. The studies of Catheart and Green ${ }^{2}$, Wilson ${ }^{3-5}$ and Basu et al. ${ }^{6}$ have demonstrated that most of the sulphur excreted as urinary sulphate in man results from the oxidation of the sulphur amino-acids absorbed in the intestine and those from tissue breakdown. It would be expected, therefore, that urinary sulphate would reflect, under certain conditions, the amount of dietary sulphur aminoacids being absorbed, thus their 'biological availability' from various foods. The present experiments were undertaken to investigate the relation between the sulphur amino-acids in the diet and the excretion of urinary inorganic sulphate in man.

A total of eight diets were tested. Their composition and nutritive values are shown in Table 1 . With each diet, the protein foods were divided into three equal parts and consumed in three meals. Subjects were allowed extra calories in the form of soft drinks and protein-free foods, but the need for additional calories was rarely felt. All the test diets provided an adequate supply of energy, vitamins and minerals. Protein was varied in type and quantity to provide a range of daily intake of $0.8-4.0 \mathrm{~g}$ methionine plus cystine.

The nitrogen content of the diets was determined using a macro-Kjeldahl method. Methionine and cystine were assayed microbiologically according to the method of Steele et al. ${ }^{8}$. Urine specimens, collected under toluene, were analysed for inorganic sulphate by the benzidine $\operatorname{method}^{8}$, for nitrogen using a macro-Kjeldahl technique ${ }^{10}$ and for ereatinine following the Jaffe procedure ${ }^{11}$. 